\title{
Structural controls on englacial esker sedimentation: Skeiðarárjökull, Iceland
}

\author{
Matthew J. BURKE, ${ }^{1}$ John WOODWARD, ${ }^{1}$ Andrew J. RUSSELL, ${ }^{2}$ P. Jay FLEISHER ${ }^{3}$ \\ ${ }^{1}$ School of Applied Sciences, Northumbria University, Newcastle upon Tyne NE1 8ST, UK \\ E-mail: matthew.burke@northumbria.ac.uk \\ ${ }^{2}$ School of Geography, Politics and Sociology, Newcastle University, Newcastle upon Tyne NE1 7RU, UK \\ ${ }^{3}$ Earth Sciences Department, State University of New York, Oneonta, NY 13820-4015, USA
}

\begin{abstract}
We have used ground-penetrating radar (GPR) to observe englacial structural control upon the development of an esker formed during a high-magnitude outburst flood (jökulhlaup). The surgetype Skeiðarárjökull, an outlet glacier of the Vatnajökull ice cap, Iceland, is a frequent source of jökulhlaups. The rising-stage waters of the November 1996 jökulhlaup travelled through a dense network of interconnected fractures that perforated the margin of the glacier. Subsequent discharge focused upon a small number of conduit outlets. Recent ice-marginal retreat has exposed a large englacial esker associated with one of these outlets. We investigated structural controls on esker genesis in April 2006, by collecting $>2.5 \mathrm{~km}$ of GPR profiles on the glacier surface up-glacier of where the esker ridge has been exposed by meltout. In lines closest to the exposed esker ridge, we interpret areas of englacial horizons up to $\sim 30 \mathrm{~m}$ wide and $\sim 10-15 \mathrm{~m}$ high as an up-glacier continuation of the esker sediments. High-amplitude, dipping horizons define the base of esker materials across many lines. Similar dipping surfaces deeper in the profiles suggest that: (1) the dipping surfaces beneath the esker are englacial tephera bands; (2) floodwaters were initially discharged along structurally controlled englacial surfaces (tephra bands); (3) the rapid increase in discharge resulted in hydrofracturing; (4) establishment of preferential flow paths resulted in conduit development along the tephra bands due to localized excavation of surrounding glacier ice; and (5) sedimentation took place within the new accommodation space to form the englacial structure melting out to produce the esker.
\end{abstract}

\section{INTRODUCTION}

Eskers are typically sinuous glaciofluvial ridges deposited in an ice-contact environment. Esker sedimentation may occur in subglacial (e.g. Brennand, 2000; Fiore and others, 2002) and englacial conduits (e.g. Price, 1969; Shulmeister, 1989), or supraglacial drainage networks (e.g. Hebrand and Åmark, 1989; Russell and others, 2001b). A subglacial origin for most esker formation has been favoured due to a general lack of post-depositional deformation (e.g. Brennand, 1994; Fiore and others, 2002), though Price (1969) suggests that englacial esker materials can be lowered (due to buried ice melt) over short distances with little disruption of esker sedimentology. Consequently, the preservation of englacially deposited eskers may be possible. Eskers have been used to infer palaeoglacial dynamics, palaeohydrology and the deglacial conditions of former ice sheets. Currently, however, there are few suitable contemporary analogues for esker formation, particularly during outburst floods (jökulhlaups), making it difficult to infer the controls on eskers formed during such events.

Recent work in the forefield of Skeiðarárjökull (an outlet glacier of the Vatnajökull ice cap, Iceland; Fig. 1) suggests pre-existing englacial structural weaknesses, such as crevasses and shear planes, are crucial to ice fracture development during a high-magnitude jökulhlaup (Roberts and others, 2001; Russell and others, 2006), but the controls on the development of major conduits during such events have not been identified. Recent retreat of Skeiðarárjökull has partially exposed a large, apparently englacial esker, connected to a supraglacial ice-walled canyon fill (Russell and others, 2006; Burke and others, 2008). This esker was formed entirely during a single high-magnitude jökulhlaup (Russell and others, 2006; Burke and others, 2008), and the controls on its sedimentary architecture have been identified by Burke and others (2008). Although suggesting that the esker was deposited englacially, Burke and others (2008) were unable to identify the mechanisms resulting in the location and growth of the conduit in which the esker was generated. The objective of this research, therefore, was to determine the controls on conduit and esker sediment location and development during a high-magnitude jökulhlaup. We used groundpenetrating radar (GPR) to image the up-glacier continuation of this englacial esker at Skeiðarárjökull and investigate the relationship between englacial structure, such as tephra bands/hydrofractures, and the esker (conduit fill) deposits.

\section{FIELD SITE}

Skeiðarárjökull is a surge-type outlet glacier (last surging in 1991) of the Vatnajökull ice cap (Fig. 1; Björnsson, 1998). It is the exit for jökulhlaups draining subglacial lake Grímsvötn (Björnsson, 2002). The last large jökulhlaup occurred because of a volcanic eruption that began under Vatnajökull on 30 September 1996 (Russell and others, 2006). Over the following month, $3.8 \mathrm{~km}^{3}$ of meltwater flowed into Grímsvötn until the critical level for drainage was reached. The resulting jökulhlaup began on 5 November in the most easterly river (Skeiðará) draining Skeiðarárjökull (Fig. 1), reaching a peak discharge of $>45000 \mathrm{~m}^{3} \mathrm{~s}^{-1}$ within 14 hours (Russell and others, 2001b). Subsequently, water burst from multiple ice-roofed vents and fractures that perforated the entire $22 \mathrm{~km}$ wide ice margin, before becoming increasingly focused upon the Gígjukvísl outlet (Russell and others, 2006). 


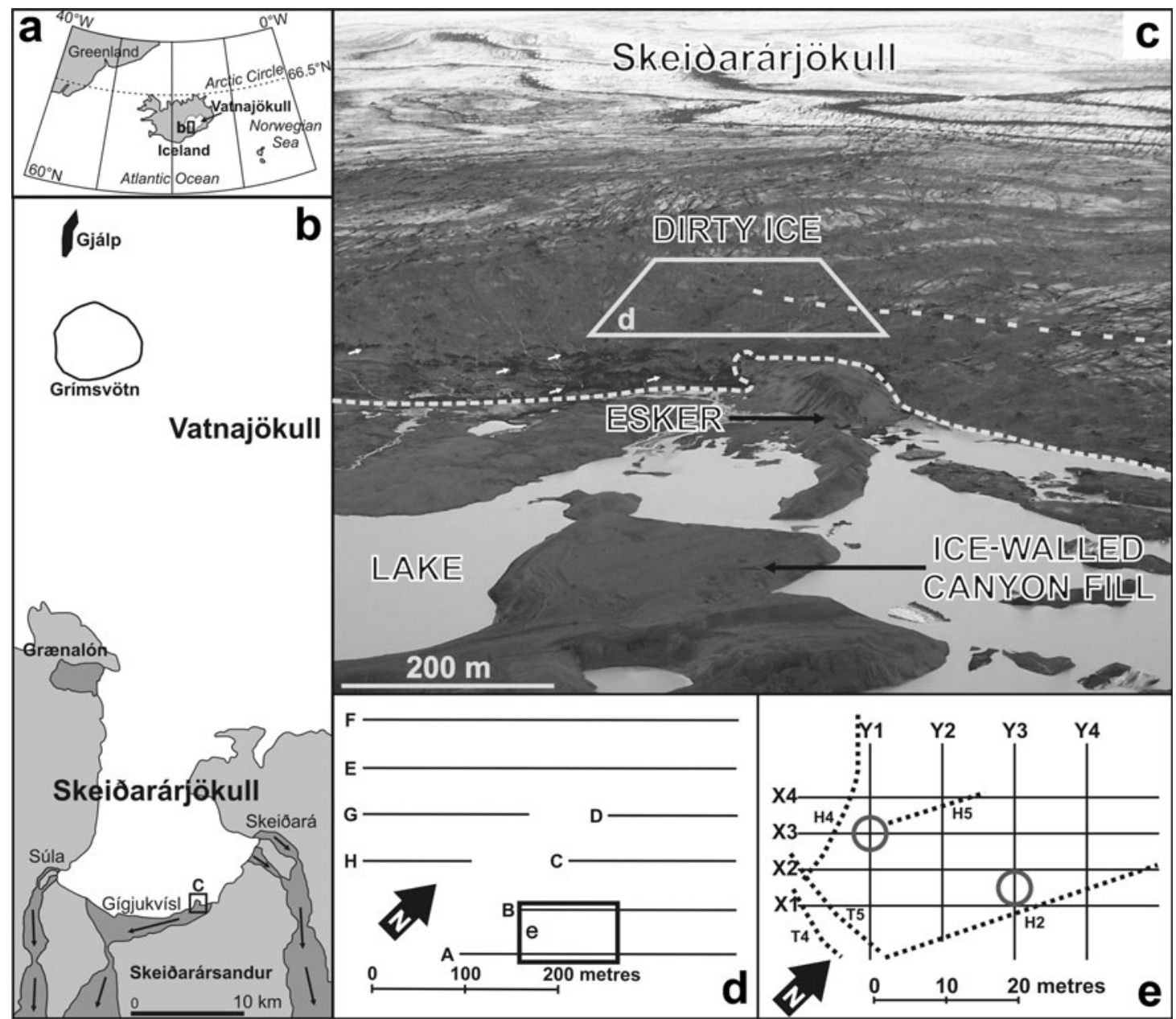

Fig. 1. The field site, with each panel in the figure containing a box highlighting the location of the subsequent panel. (a) Location of the Vatnajökull ice cap, with Skeiðarárjökull being indicated by box b. (b) Skeiðarárjökull, showing the location of subglacial lake Grímsvötn, the 1996 eruption site (Gjálp) and peak proglacial flood routing (arrows) during the 1996 Skeiðarárhlaup (the darker shading indicates water bodies). The box indicates the location of (c). (c) An oblique view of the margin of Skeiðarárjökull in the area of the esker and ice-walled canyon landforms, with the location of the glacier margin being highlighted by the narrow dashed line and grid 1 being indicated by box $d$. The folded bands on the glacier surface are associated with tephra bands, whilst the ridges of dark material on the ice surface (white arrows) are partially melted-out hydrofracture fills. The wide dashed line highlights an example of a long, continuous tephra band that is outcropping on the glacier surface. (d) GPR lines collected as part of grid 1, with the box indicating the location of grid 2. (e) GPR lines collected as part of grid 2. The centre points of common-midpoint (CMP) GPR profiles are circled and the positions of dipping structure outcropping on the glacier surface are indicated by the labelled dashed lines.

Here, supraglacial drainage continued into the late-rising, peak and early-waning stages of the jökulhlaup, with flows exiting from a supraglacial fracture network (Cassidy and others, 2003). Near-surface ice excavation led to the development of an ice-walled canyon within which the floodwaters deposited thick sedimentary sequences (Russell and others, 2001b; Cassidy and others, 2003). Subsequently, rapid rates of glacier surface lowering have exposed the canyon deposit and an esker. The esker extends continuously for a distance of $>700 \mathrm{~m}$ from the proximal end of the canyon deposits to the ice margin (July 2006), and additional esker material melts out of the ice margin every summer. The esker is largely continuous for its entire length and is slightly sinuous in morphology (Fig. 2a and b). Its surface topography is, in places, irregular, with a tendency towards greater elevations on the western side and a multiple-crested appearance (Fig. 2c). Controls on the internal sedimentary architecture of the esker have been linked to conduit geometry, hydrological conditions and sediment supply (Burke and others, 2008).
At the GPR survey site, in addition to the esker, two suites of sedimentary structure are being exposed by meltout at the glacier surface (Fig. 2d). The first suite of structures represents gently up-glacier dipping bands of tephra, deposited on the glacier surface in the accumulation zone and transported englacially to the glacier margin. The second suite has been identified as hydrofracture fills which contain internal bedding consistent with sediment accretion via freezing of supercooled floodwaters within fractures formed during the November 1996 jökulhlaup (Roberts and others 2001). In outcrops, these englacial structures form a complex pattern of steeply inclined, down-glacier dipping sediment bands (Fig. 2).

\section{METHODOLOGY}

In April 2006, two grids of $100 \mathrm{MHz}$ GPR common-offset (CO) lines were collected on the surface of Skeiðarárjökull, up-glacier from the partially exposed jökulhlaup-generated esker (Fig. 1) using a pulseEKKO Pro 1100 system. For all 

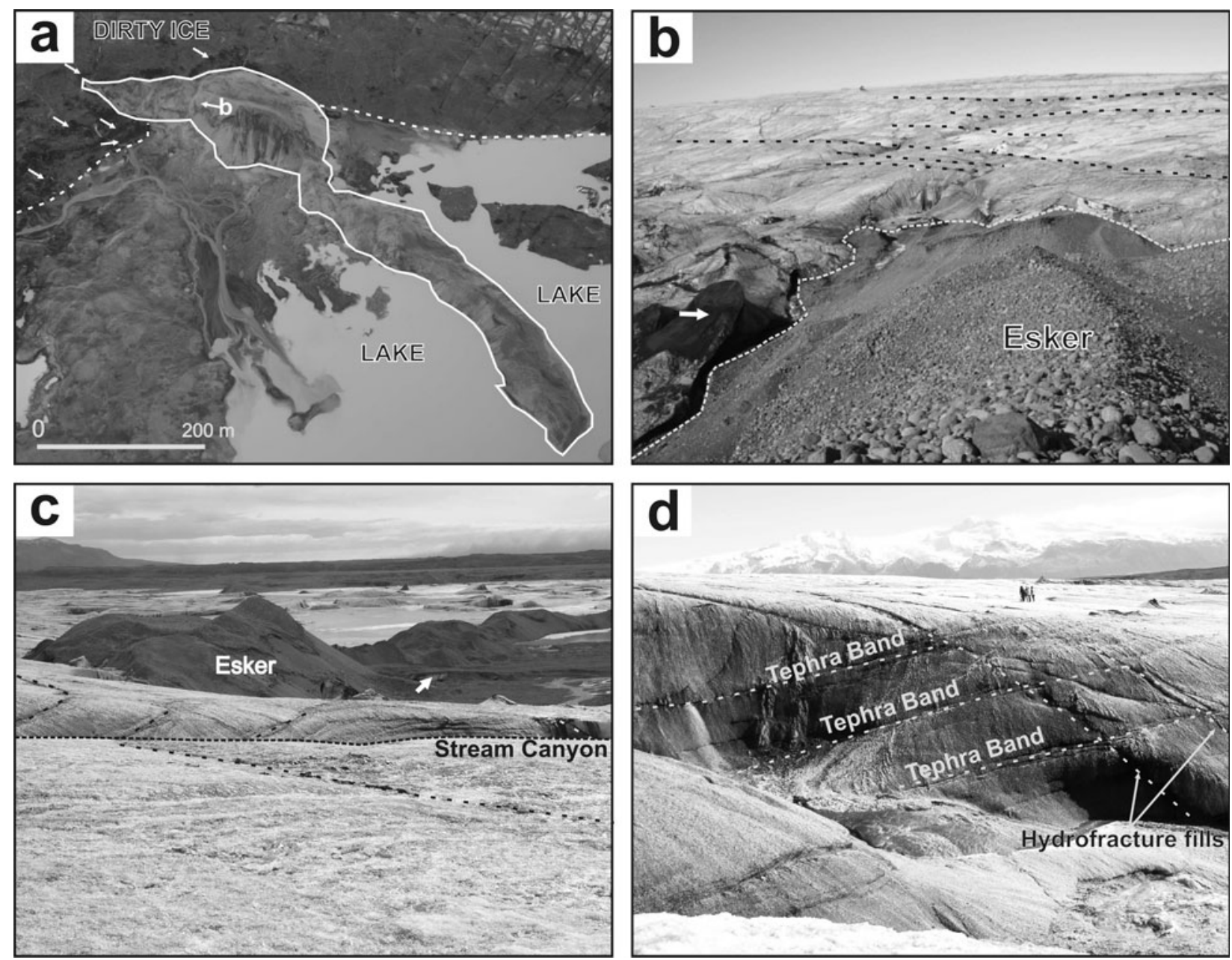

Fig. 2. Photographs of the esker, which has progressively melted out from the glacier margin since 2002, and englacial structure observed in the field area. (a) Aerial photograph (July 2006) of the esker (highlighted by solid line), showing its continuous and slightly sinuous morphology, with the ridge narrowing down-flow of an enlargement at the head of the exposed esker. The dashed line indicates the ice margin, and the arrows point to hydrofracture fills that are melting out at the glacier surface. The position and orientation of (b) are shown by the letter and arrow, respectively. (b) The glacier surface from the esker (April 2006). The narrow dashed line indicates the ice margin, whilst the wide dashed lines highlight tephra bands outcropping on the glacier surface. The arrow points to a down-glacier dipping hydrofracture fill that is melting out at the glacier margin. (c) The esker, taken from the glacier surface (April 2006). The esker has an irregular morphology, and is double-crested in places. In stream canyons on the glacier surface, up- and down-glacier dipping structure can be observed in the ice walls. (d) Tephra bands and hydrofracture fills within the glacier, some of which are highlighted by the dashed lines.

GPR data collection the antennae were co-polarized, perpendicular to the survey line, with their broadsides orientated towards each other to reduce reflections from offset sources. In addition, data were collected in step mode to allow better antennae ground coupling and trace stacking (32 traces). Grid 1 lines were collected at a trace spacing of $0.5 \mathrm{~m}$, with the $400 \mathrm{~m}$ long GPR lines being spaced at $50 \mathrm{~m}$ intervals up-glacier (Fig. 1d). The grid was located immediately up-glacier from the point at which the esker is being exposed by ice-marginal retreat. Grid 2 was collected in an area in which englacial horizons were identified on line $A$ of grid 1 (Fig. 1e). Grid 2 lines were spaced every $10 \mathrm{~m}$ upglacier and $20 \mathrm{~m}$ across glacier and were collected with a trace spacing of $0.2 \mathrm{~m}$. Two common-midpoint (CMP) profiles collected on grid 2 (Fig. 1e) provided an estimated subsurface average velocity of $0.137 \pm 0.009 \mathrm{~m} \mathrm{~ns}^{-1}$, consistent with that for temperate, sediment-rich ice (Murray and others, 2000b). Data processing using REFLEXW version 4.2 (Sandmeier, 2006) included time-zero correction, high-pass filtering, bandpass filtering, migration, background removal, application of a gain function and topographic correction (following the methodology of Woodward and others, 2003). The GPR lines and major supraglacial structure within the grids were mapped using global positioning system (GPS) to allow correlation with GPR profiles (Fig. 1e).

\section{RESULTS AND DISCUSSION Description of GPR lines}

In general, the pervasiveness of near-surface debris-filled structure, coupled with the temperate ice environment, made for poor radar performance. Some horizons, however, could be identified on grids 1 and 2, which are described below.

\section{Grid 1}

On line A (Fig. 3), grid 1, two near-surface zones of scattering (labelled S in Fig. 3b) can be identified at 155 and 240 m. On all grid 1 GPR lines, two suites of dipping englacial horizons 


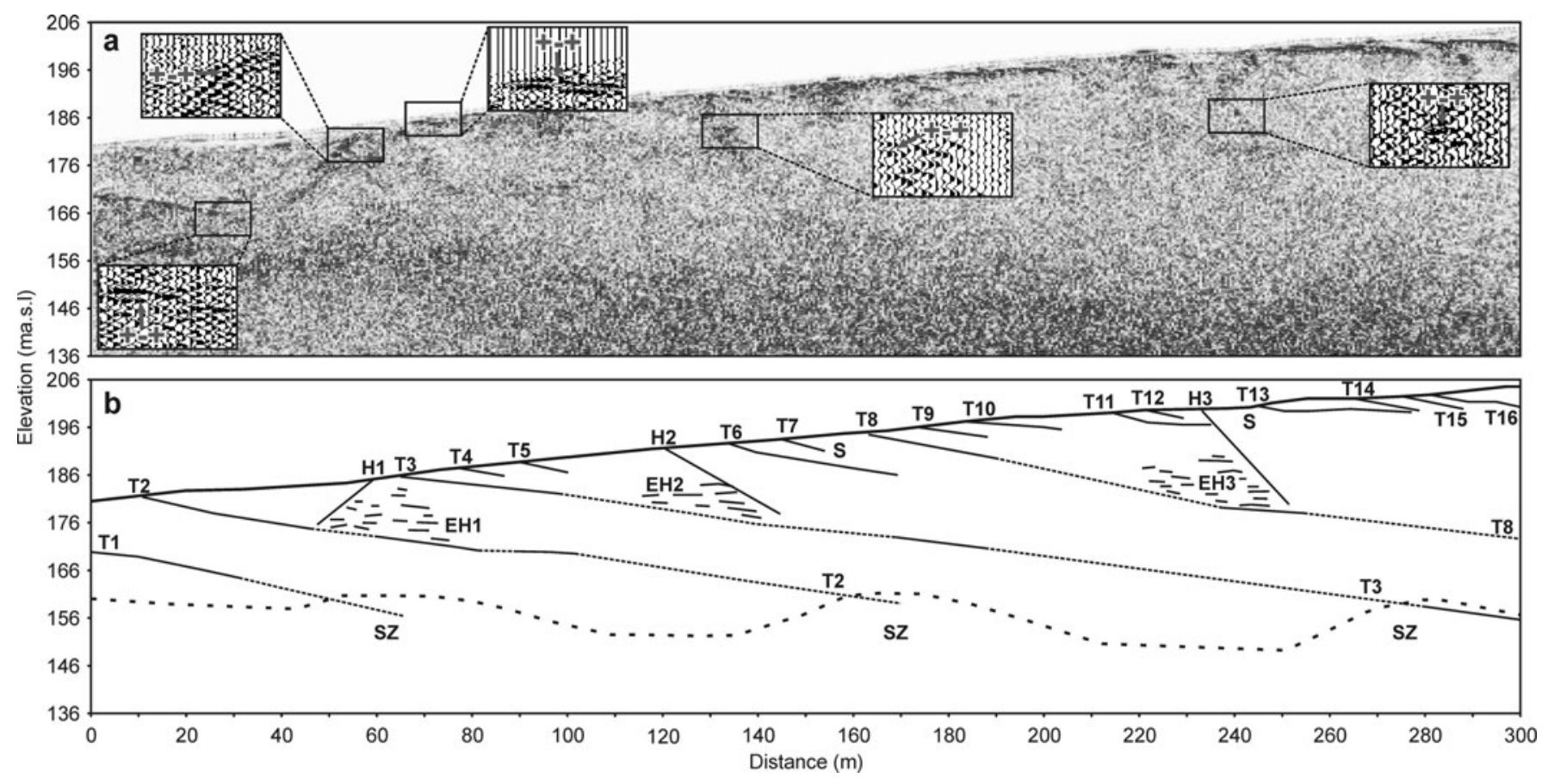

Fig. 3. (a) Processed GPR line A of grid 1. The enlargements show waveform plots identifying the wavelet polarity of the major horizon types identified. In all cases, a positive-negative-positive wavelet (+-+) is produced, because of an increase in the $\varepsilon_{\mathrm{r}}$ across the interface and a decrease in velocity for the materials creating the horizon. (b) Interpretation of line A: the wide dashed line represents the approximate position of a transition to a basal zone of increased scatter (SZ). At the near-surface, two suites of dipping horizons can be identified and are labelled $\mathrm{T}$ and $\mathrm{H}$. Three areas of englacial horizons $(\mathrm{EH})$ are identified. The bases of the $\mathrm{EH}$ are defined by englacial dipping horizons $(\mathrm{T})$, the amplitudes of which vary along the line, with weaker-amplitude sections indicated by a narrow dashed line. Two near-surface zones of scattering can be identified and correlated to supraglacial streams (S) at the time of data collection.

can be traced from the glacier surface to varying depths within the profile. The first suite of englacial horizons, labelled ' $\mathrm{T}$ ' in Figure 3, typically dip at angles of $1-10^{\circ}$ oblique to the ice margin. Most horizons can only be traced in the near-surface for distances of $<20 \mathrm{~m}$, though in line $\mathrm{A}$ (Fig. 3) three of the structures, at $12 \mathrm{~m}$ (T2), $65 \mathrm{~m}$ (T3) and $165 \mathrm{~m}$ (T8), can be traced for distances $>150 \mathrm{~m}$ before signal scatter prevents further tracing. The reflection amplitude along the horizon varies, with the solid-line interpretations in Figure 3 corresponding to high-amplitude horizons (e.g. T3 between 170 and $190 \mathrm{~m}$ ), whilst the narrow-dashed-line interpretations correspond to low-amplitude horizons (e.g. T3 between 100 and $170 \mathrm{~m}$ ). The second suite of englacial horizons, labelled $\mathrm{H}$ in Figure 3, dip at angles of $30-50^{\circ}$ in varying orientations. On line $A$, horizons can be traced for $\sim 20 \mathrm{~m}$ from the glacier surface at $58 \mathrm{~m}(\mathrm{H} 1), 125 \mathrm{~m}(\mathrm{H} 2)$ and $235 \mathrm{~m}(\mathrm{H} 3)$ as continuous high-amplitude horizons.

Three areas of englacial horizons $(\mathrm{EH})$ can also be identified on line A (Fig. 3), at distances of 50-70 m (EH1), 115-140 m (EH2) and 220-240 m (EH3). They are composed of horizons of varying amplitude, often showing little lateral continuity (Fig. 3). In Figure 3, EH1, EH2 and $\mathrm{EH} 3$ are located directly above T2, T3 and T8, respectively. The steeply inclined dipping horizons $\mathrm{H} 1-\mathrm{H} 3$ are found in close association with the lateral margins of EH1-EH3 (Fig. 3).

In addition to the major englacial features described above, each grid 1 GPR line shows an increase in englacial scattering with depth, which results in rapid GPR signal attenuation below $156 \mathrm{~m}$ a.s.l. (see Fig. 3 for an example). In Figure 3, the transition to this zone of increased scatter is broadly indicated by the wide dashed line labelled SZ. The depth of SZ is irregular across each GPR line.

\section{Grid 2}

Grid 2 was collected between lines A and B of grid 1 in the area in which $\mathrm{EH} 2$ was identified in line A (Fig. 4). The interconnection of grid 2 with lines A and B has allowed the tracing of horizons through the grid. This higher-resolution grid allows a pseudo-three-dimensional visualization of structure within the area immediately up-glacier of the emerging esker sediments (Fig. 4c-f). On line X1 of Figure 4, a near-surface zone of scatter (labelled $\mathrm{S}$ ) can be identified at $160 \mathrm{~m}$. As on grid 1, at the near-surface, two suites of dipping horizons can also be discerned (Fig. 4). The first suite of englacial horizons (T) typically dip at angles of $1-10^{\circ}$ (southwest-northeast) and $1-5^{\circ}$ (southeast-northwest), in an orientation oblique to the ice margin. As in Figure 3, these near-surface dipping horizons can commonly be traced for $<20 \mathrm{~m}$, though the more continuous T3, which could be traced from the glacier surface on line $A$, can also be traced through grid 2. This horizon forms an undulating surface across the grid, with an overall dip from southwest to northeast at an angle of $\sim 10^{\circ}$ (Fig. $4 \mathrm{e}$ ). Although variations in horizon amplitude (Fig. 4) result in a slightly discontinuous presence to the horizon, it can be traced through most of the grid, with solid-line interpretations corresponding to higheramplitude horizons and lower-amplitude sections being indicated by the narrow dashed line (Fig. 4). The second suite of englacial horizons are less common, typically dipping at angles of $20-30^{\circ}$ (northwest-southeast) and 30-70 (southwest-northeast), dipping down-glacier $(\mathrm{H})$. As on line $\mathrm{A}, \mathrm{H}$ can be traced from the glacier surface for distances up to $20 \mathrm{~m}$ and in some cases cross-cut T (Fig. 4).

$\mathrm{EH} 2$ identified and described from line A of grid 1 (Fig. 3) can be traced through grid 2, forming a large englacial 

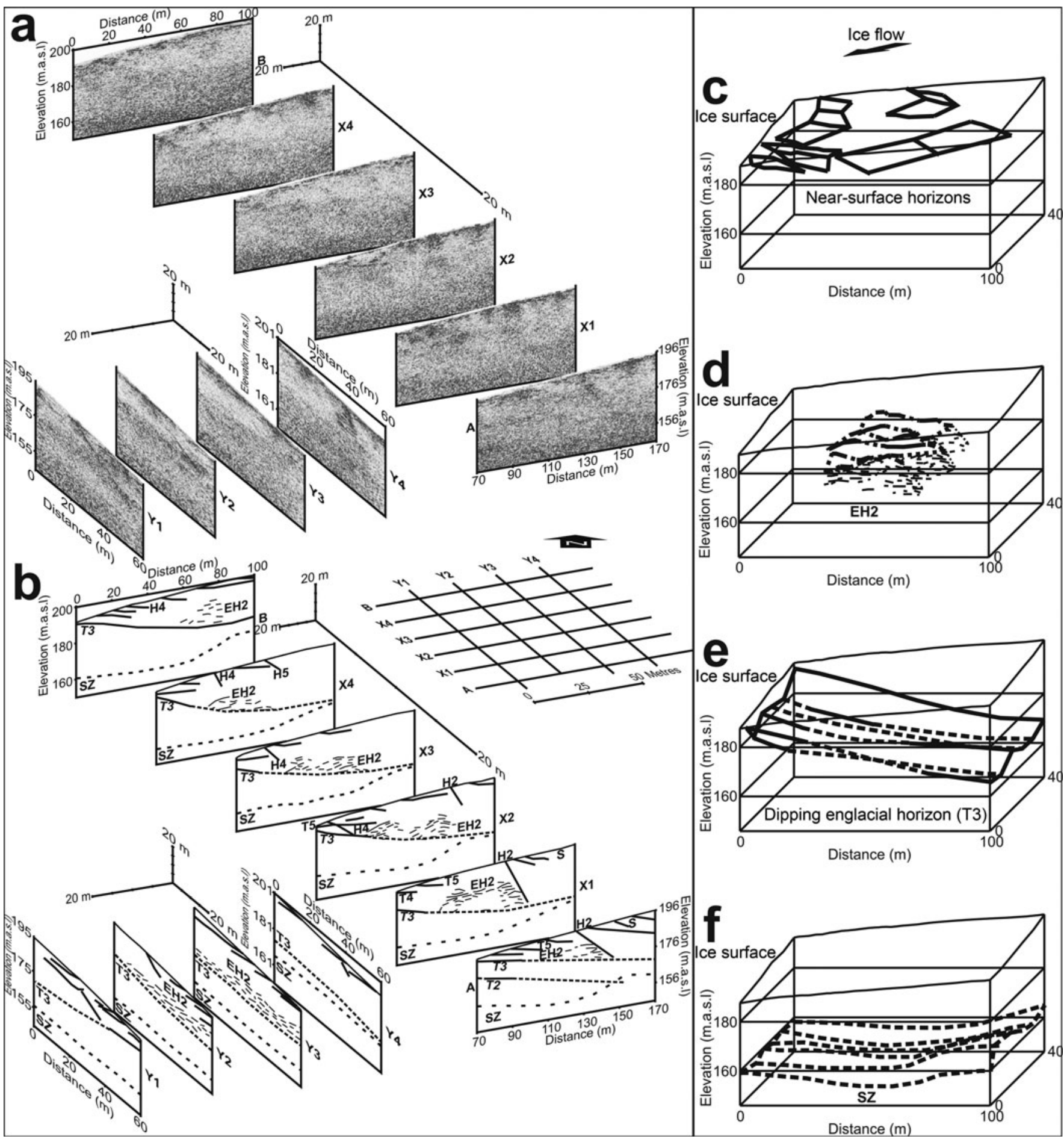

Fig. 4. (a, b) Fence diagram of processed grid 2 GPR lines (a) and subsequent interpretation (b). The basal scatter zone (SZ), dipping englacial horizon labelled T3 (sections represented by narrow dashed line are lower-amplitude horizons) and the englacial horizons (EH2) can be traced across significant parts of the grid and visualized pseudo-three-dimensionally (c-f). Two suites of englacial dipping horizons are identified and labelled T and H. (c) Near-surface dipping horizons. (d) Englacial horizons (EH2). The upper surface (bold) and some deeper $\mathrm{EH}$ are plotted. (e) Continuous dipping englacial horizon (T3). The horizon amplitude varies and weaker signals are indicated by the dashed lines. (f) The approximate position of the transition from reflection-poor ice to a zone of scattering (SZ).

feature, the imaged part of which is $\sim 10 \mathrm{~m}$ high, $\sim 20 \mathrm{~m}$ wide and $\sim 60 \mathrm{~m}$ long (Fig. 4d). Horizons within $\mathrm{EH} 2$ are typically discontinuous and irregular and a number of diffractions can be identified. T3 defines the base of EH2 throughout the grid (Fig. 4). In some places (e.g. distance $100 \mathrm{~m}$ on line $\mathrm{X} 2$ and $55 \mathrm{~m}$ on line Y2) the upper englacial horizons appear to have a close association with other nearsurface dipping horizons. The maximum elevation of $\mathrm{EH} 2$ corresponds to the position of a series of near-surface dipping horizons, and the western flank of EH2 appears to be defined by a steeply inclined horizon labelled H3 (Fig. 4).

As in Figure 3, each grid 2 GPR line shows an increase in englacial scattering with depth, which results in rapid attenuation at depths below 156 ma.s.l. In Figure 4, the transition to this zone of increased scatter is approximately indicated by the wide dashed line labelled SZ. The depth of 
SZ is irregular along the GPR lines, but has a consistent pattern through the grid (Fig. 4f).

\section{Analysis of waveform polarity}

Examination of the waveform of the dipping horizons and $\mathrm{EH}$ in Figure 3 (line A) can give some indication of the type of materials associated with the horizons. The phase polarity sequence of a reflected (one-and-a-half-cycle) wavelet depends on that of the transmitted wavelet and of the reflection coefficient (Arcone and others, 1995). Examination of CMP surveys shows that the airwave appears positive-negative-positive (+-+), whilst the waveform of the ice wave has an opposite phase polarity, appearing negative-positive-negative (-+-). Reflections from interfaces where the relative dielectric permittivity $\left(\varepsilon_{\mathrm{r}}\right)$ decreases (velocity increases) will not be phase-shifted relative to the ice wave and will appear -+- (Murray and others, 2000b). If the $\varepsilon_{\mathrm{r}}$ increases (velocity decreases) downward across the reflection interface, then the phase polarity of the transmitted wavelet will invert (+-+) relative to the ice wave (Murray and others, 2000b). The wavelets of near-surface and englacial dipping horizons ( $\mathrm{T}$ and $\mathrm{H}$ ), as well as $\mathrm{EH} 1-\mathrm{EH} 3$ give a positive-negative-positive (+-+) reflection, suggesting an increase in the $\varepsilon_{\mathrm{r}}$ (decrease in velocity). This is consistent with a transition from temperate ice to either sediment-rich ice or ice containing greater water content (Murray and others, 2000b).

\section{Interpretation}

Scatter from water and sediment inclusions has made horizon interpretation challenging. As at other temperate glaciers (Murray and others, 2000a; Navarro and others, 2005), significant amounts of free water are found at Skeiðarárjökull, both as supraglacial streams and as interstitial and water lenses within the ice. This strongly scatters electromagnetic waves. In addition, Skeiðarárjökull is subject to surging, jökulhlaups, and tephra deposition from volcanic eruptions, resulting in the inclusion of significant quantities of sediment within englacial ice (Roberts and others, 2001; Russell and others 2001a). Such englacial sediment structures can be observed melting out at the glacier surface, and in the ablation season form a thin veneer of sediment that covers the ice surface (Fig. 1c).

\section{Near-surface scatters $(S)$}

Two near-surface zones of scattering can be identified in grids 1 and 2. Although the extent of supraglacial melting was relatively low during data collection, a number of supraglacial streams flowed across the glacier surface in the field area. The near-surface scatter zones labelled $S$ in Figures 3 and 4 correspond to the position of such streams and are consequently interpreted as supraglacial streams, consistent with interpretations at other glaciers (e.g. Murray and others, 2000a; Woodward and others, 2003).

\section{Low-angle dipping horizons $(T)$}

Low-angle dipping horizons could be identified within all GPR lines, with many occurring at similar angles and orientations (typically around $10^{\circ}$ ). The tracing of some horizons to tephra bands outcropping on the glacier surface at the time of data collection (Figs 3 and 4) that have similar orientations to the dipping horizons (Figs 1c and 2), combined with a waveform consistent with a velocity reduction, suggests that the horizons represent tephra bands within the ice. The extent to which these tephra bands can be traced into the ice, as well as reflection amplitude are variable across both grids and are likely to be linked to variations in layer thickness and/or chemical composition. The thickness of a tephra band is controlled by the amount of tephra deposited (dependent upon the size of the eruption and the distance from the eruption site), as well as ice-flow rate and characteristics. Where tephra bands are thicker, a high-amplitude horizon is produced that can be traced for considerable distances beneath the glacier surface.

\section{High-angle dipping horizons $(H)$}

High-angle dipping horizons could be identified within all GPR lines, showing variable angles of dip and orientation. Some of these horizons could be traced to sediment-filled hydrofractures outcropping on the glacier surface. Waveform analysis is consistent with a velocity reduction at the interface, i.e. a change from ice to sediment, suggesting these horizons represent hydrofracture fills generated during the November 1996 jökulhlaup (Skeiðarárhlaup).

\section{Englacial horizons (EH)}

Although the radar signal at depth within the profiles is weak, due to dielectric absorption and scattering by nearsurface structure and water bodies, the areas of englacial horizons identified on lines $\mathrm{A}$ and $\mathrm{B}$ of grid 1 and in grid 2 $(\mathrm{EH} 2)$ are interpreted to represent the englacial continuation of the jökulhlaup esker for three reasons: (1) the anomalous areas of horizons are relatively consistent through grid 2; (2) the irregular upper surface of the englacial horizons identified from pseudo-three-dimensional surveys (Fig. 4d) is consistent with the morphology of the exposed section of the esker (Fig. 2; Burke and others, 2008); and (3) these areas of englacial horizons are located just up-glacier from the position where the esker is emerging from the glacier margin (Figs 1c and 2). As the base of all esker materials is defined by tephra bands T2, T3 and T8, the conduit probably developed along these planes. The esker materials also show close association with the steeply inclined horizons representing the hydrofracture fills $(\mathrm{H})$.

\section{Basal transition to increased scatter (SZ)}

The basal zone of scatter can be interpreted to represent either basal ice or an increase in water inclusions. As the survey was conducted in April, there was relatively little supraglacial melting, suggesting that this basal zone of diffractions is caused by the piezometric surface, with its characteristics being similar to those reported from other temperate glaciers (e.g. Murray and others, 2000a). Local variations in the height of the piezometric surface are likely caused by water that has infiltrated the glacier through englacial debris-filled structure.

\section{Discussion}

The traditional view of a glacial hydrological system is that water routed towards the glacier bed is controlled by variations in hydraulic potential (e.g. Shreve, 1972), with water entering through crevasses and moulins (Hooke, 1989; Fountain and Walder, 1998) to form an upwardsbranching arborescent network (Shreve, 1972). This applies to steady-state scenarios only. The November 1996 Skeiðarárhlaup was not steady-state. This research has identified a suite of englacial structures at Skeiðarárjökull that enable the 
controls on the development of conduits during highmagnitude jökulhlaups. They are:

1. During the early rising stage of the November 1996 Skeiðarárhlaup, pre-existing conduits could not respond rapidly enough to the transient input of floodwaters. Consequently, new outlets had to be created (Roberts and others, 2001). The November 1996 Skeiðarárhlaup appears to have flowed subglacially for some distance, before becoming englacial towards the margin. The englacial routing of the 1996 Skeiðarárhlaup waters was probably controlled by pre-existing tephra bands, filled with porous sediments, which provided the most direct route to the glacier margin, as suggested by Gulley and Benn (2007) for englacial drainage within debris-covered glaciers.

2. The rate of discharge increase during the November 1996 Skeiðarárhlaup exceeded the rate at which floodwaters could be expelled along these pre-existing lines of weakness. Consequently, hydrofractures were developed from these flow paths, before being infilled with glaciofluvial sediment through accretion of sedimentladen supercooled water.

3. As the jökulhlaup progressed, floodwaters became focused upon preferential flow paths, where englacial conduits developed through the mechanical excavation of the surrounding ice. During the late-rising and waning stages of the flood, these englacial conduits were infilled by glaciofluvial sediments to form the englacial esker, the sedimentary architecture of which was controlled by conduit geometry, flow conditions and sediment supply (Burke and others, 2008).

\section{CONCLUSIONS}

Over $2.5 \mathrm{~km}$ of GPR line were collected at Skeiðarárjökull, up-glacier from an englacial esker that is emerging from the glacier margin. In general, the pervasiveness of near-surface debris-filled structure, coupled with the temperate ice environment, made for poor radar performance. In lines closest to where the esker is emerging from the glacier margin, however, areas of englacial horizons could be identified. We conclude that these englacial horizons are esker material, the bases of which are defined by dipping horizons we interpret as surfaces associated with tephra bands. We suggest that jökulhlaup waters were initially discharged along these pre-existing tephra bands, before the negative effective pressures forced hydrofracturing of the ice and englacial conduit and esker development along preferential flow paths through mechanical excavation. These observations contrast with current models of jökulhlaup discharge, where the basic assumption of conduit growth and decay is that this is controlled by the balance between frictional melting and creep closure (e.g. Flowers and others, 2004). In addition, while the importance of structural control, rather than potential gradients within the ice, upon glacial hydrology is not a new concept (Fountain and Walder, 1998; Fountain and others, 2005; Gulley and Benn, 2007), this study provides the first evidence for the importance of structure in the development of major conduit outlets and esker sedimentation during a high-magnitude jökulhlaup. Understanding and quantifying the nature of structural controls may be crucial to successfully simulating high-magnitude jökulhlaups, as well as predicting flood routing, outlet development and landform formation during flood events.

This study has provided an insight into the controls on englacial conduit location and development during a highmagnitude jökulhlaup. As this esker system may prove analogous to the eskers formed beneath the Last Glacial Maximum ice sheets in North America and Europe, results suggest care must be taken when attempting to reconstruct potential gradients and palaeo-ice-sheet characteristics from esker features.

\section{ACKNOWLEDGEMENTS}

Fieldwork was supported by The Earthwatch Institute. We thank D. Blauvelt, A. Gregory, A. Large and Earthwatch volunteers for assistance during the fieldwork, as well as R.F. Kristjánsson for supporting our research in Skaftafell National Park. We also thank S. Arcone, N. Glasser and an anonymous reviewer for constructive comments that significantly improved the paper.

\section{REFERENCES}

Arcone, S.A., D.E. Lawson and A.J. Delaney. 1995. Short-pulse radar wavelet recovery and resolution of dielectric contrasts within englacial and basal ice of Matanuska Glacier, Alaska, U.S.A. J. Glaciol., 41(137), 68-86.

Björnsson, H. 1998. Hydrological characteristics of the drainage system beneath a surging glacier. Nature, 395(6704), 771-774.

Björnsson, H. 2002. Subglacial lakes and jökulhlaups in Iceland. Global Planet. Change, 35(3-4), 255-271.

Brennand, T.A. 1994. Macroforms, large bedforms and rhythmic sedimentary sequences in subglacial eskers, south-central Ontario: implications for esker genesis and meltwater regime. Sediment. Geol., 91(1-4), 9-55.

Brennand, T.A. 2000. Deglacial meltwater drainage and glaciodynamics: inferences from Laurentide eskers, Canada. Geomorphology, 32(3), 263-293.

Burke, M.J., J. Woodward, A.J. Russell, P.J. Fleisher and P.K. Bailey. 2008. Controls on the sedimentary architecture of a single event englacial esker: Skeiðarárjökull, Iceland. Quat. Sci. Rev., 27(19-20), 1829-1847.

Cassidy, N.J. and 6 others. 2003. GPR derived architecture of November 1996 jökulhlaup deposits, Skeiðarársandur, Iceland. Geol. Soc. London Spec. Publ. 211, 153-166.

Fiore, J., A. Pugin and M. Beres. 2002. Sedimentological and GPR studies of subglacial deposits in the Joux Valley (Vaud, Switzerland): backset accretion in an esker followed by an erosive jökulhlaup. Geogr. Phys. Quat., 56(1), 19-32.

Flowers, G.E., H. Björnsson, R. Pálsson and G.K.C. Clarke. 2004. A coupled sheet-conduit mechanism for jökulhlaup propagation. Geophys. Res. Lett., 31(5), L05401. (10.1029/2003GL019088.)

Fountain, A.G. and J.S. Walder. 1998. Water flow through temperate glaciers. Rev. Geophys., 36(3), 299-328.

Fountain, A.G., R.W. Jacobel, R. Schlichting and P. Jansson. 2005. Fractures as the main pathways of water flow in temperate glaciers. Nature, 433(7026), 618-621.

Gulley, J. and D.I. Benn. 2007. Structural control of englacial drainage systems in Himalayan debris-covered glaciers. J. Glaciol., 53(182), 399-412.

Hebrand, M. and M. Åmark. 1989. Esker formation and glacier dynamics in eastern Skåne and adjacent areas, southern Sweden. Boreas, 18(1), 67-81.

Hooke, R.LeB. 1989. Englacial and subglacial hydrology: a qualitative review. Arct. Alp. Res., 21(3), 221-233. 
Murray, T., G.W. Stuart, M. Fry, N.H. Gamble and M.D. Crabtree. 2000a. Englacial water distribution in a temperate glacier from surface and borehole radar velocity analysis. J. Glaciol., 46(154), 389-398.

Murray, T. and 6 others. 2000b. Glacier surge propagation by thermal evolution at the bed. J. Geophys. Res., 105(B6), 13,491-13,507.

Navarro, F.J., Yu.Ya. Macheret and B. Benjumea. 2005. Application of radar and seismic methods for the investigation of temperate glaciers. J. Appl. Geophys., 57(3), 193-211.

Price, R.J. 1969. Moraines, sandar, kames and eskers near Breiðamerkurjökull, Iceland. Inst. Br. Geogr. Trans., 46, 17-43.

Roberts, M.J., A.J. Russell, F.S. Tweed and O. Knudsen. 2001. Controls on englacial sediment deposition during the November 1996 jökulhlaup, Skeiðarárjökull, Iceland. Earth Surf. Process. Landf., 26(9), 935-952.

Russell, A.J., P.G. Knight and T.A.G.P. van Dijk. 2001a. Glacier surging as a control on the development of proglacial, fluvial landforms and deposits, Skeiðarársandur, Iceland. Global Planet. Change, 28(1-4), 163-174.
Russell, A.J., Ó. Knudsen, H. Fay, P.M. Marren, J. Heinz and J. Tronicke. 2001b. Morphology and sedimentology of a giant supraglacial, ice-walled, Jökulhlaup channel Skeiðarárjökull, Iceland: implications for esker genesis. Global Planet. Change, 28(1-4), 193-216.

Russell, A.J. and 6 others. 2006. Icelandic jökulhlaup impacts: implications for ice-sheet hydrology, sediment transfer and geomorphology. Geomorphology, 75(1-2), 33-64.

Sandmeier, K.J. 2006. REFLEXW: processing program for seismic, acoustic and electromagnetic reflection, refraction and transmission data. Version 4.2. Karlsruhe, Sandmeier Scientific Software.

Shreve, R.L. 1972. Movement of water in glaciers. J. Glaciol., 11(62), 205-214.

Shulmeister, J. 1989. Flood deposits in the Tweed Esker (southern Ontario, Canada). Sediment. Geol., 65(1-2), 153-163.

Woodward, J., T. Murray, R.A. Clark and G.W. Stuart. 2003. Glacier surge mechanisms inferred from ground-penetrating radar: Kongsvegen, Svalbard. J. Glaciol., 49(167), 473-480. 